\title{
THE RELATION OF FORESTS AND FOREST FIRES
}

\author{
Gifford Pinchot
}

\section{Forester of the U.S. Department of Agriculture}

The study of forest fires as modifiers of the composition and mode of life of the forest is as yet in its earliest stages. Remarkably little attention, in the view of the importance of the subject, has hitherto been accorded it. A few observers who have lived much with the forest, such as John Muir of California, have grouped fire with temperature and moisture as one of the great factors which govern the distribution and character of forest growth; but so little has been said or written upon the subject that the opinion of each man seems to have been reached independently and upon the single basis of personal observation. The documents upon the subject still reside, with very few exceptions, in the forest itself. It is unfortunate that our acquaintance with what might also be called the creative action of forest fires should be so meager, for only through a knowledge of this relation and through the insight which such knowledge brings can there be gained a clear and full conception of how and why fires burn, and how they may be prevented or extinguished.

The records of past fires, written in the forest now on the ground, are often decipherable for a hundred years back, and in many cases for more than twice that length of time. Such records throw light on the relations of forests and fires as nothing else can, and are consequently the most valuable of all documents upon the somewhat intricate but most important question of the final effect of fire on the forest; for we must clearly realize, before the present subject can fall into its proper sequence, that we have not stated everything when we say that "a given forest is destroyed by fire." The forests which the first white explorers saw as they landed on this continent and gradually overran it were themselves the successors of others, which, through thousands of years, were burned down at intervals that we can no longer trace. There is but little of all of the vast forest area of this country which does not bear, either in actual scars and charcoal or in the manner and composition of its growth, the marks of fire, and indeed it is more probable that further investigation will greatly narrow the limits of those portions which may now seem to have been exempt.

That fires do vast harm we know already, although just what the destruction of its forests will cost the nation is not known (Figure 1). Records compiled by the Division of Forestry indicate that the average direct recorded loss from this source is not less than $\$ 20,000,000$ a year. To this figure must be added the vast direct loss unrecorded, together with a great but indefinite damage from the effect of forest destruction on water supply, and other losses of immense importance, the deterioration of the soil, the destruction of the young growth, and the loss of the increment which a healthy young forest would have been laying on year after year. With further study a more exact statement of the grand total of the loss will be possible; but even now it is safe to assume that for the nation as a whole the loss is represented yearly by a sum much in excess of $\$ 50,000,000$ (Figure 2). That figure sufficiently proves that the destructive action of fire on the forest in relation to human needs is a subject of the first interest and importance; but in the present paper this brief reference must suffice. The regulative action of fire on the forest is here more directly in question.

Fires determine the presence or absence of forest in a given region far more generally than is often supposed. A very large part of the prairie regions of the United States is treeless probably because of fire (Figure 3). Such evidence as we have points strongly in this direc- 


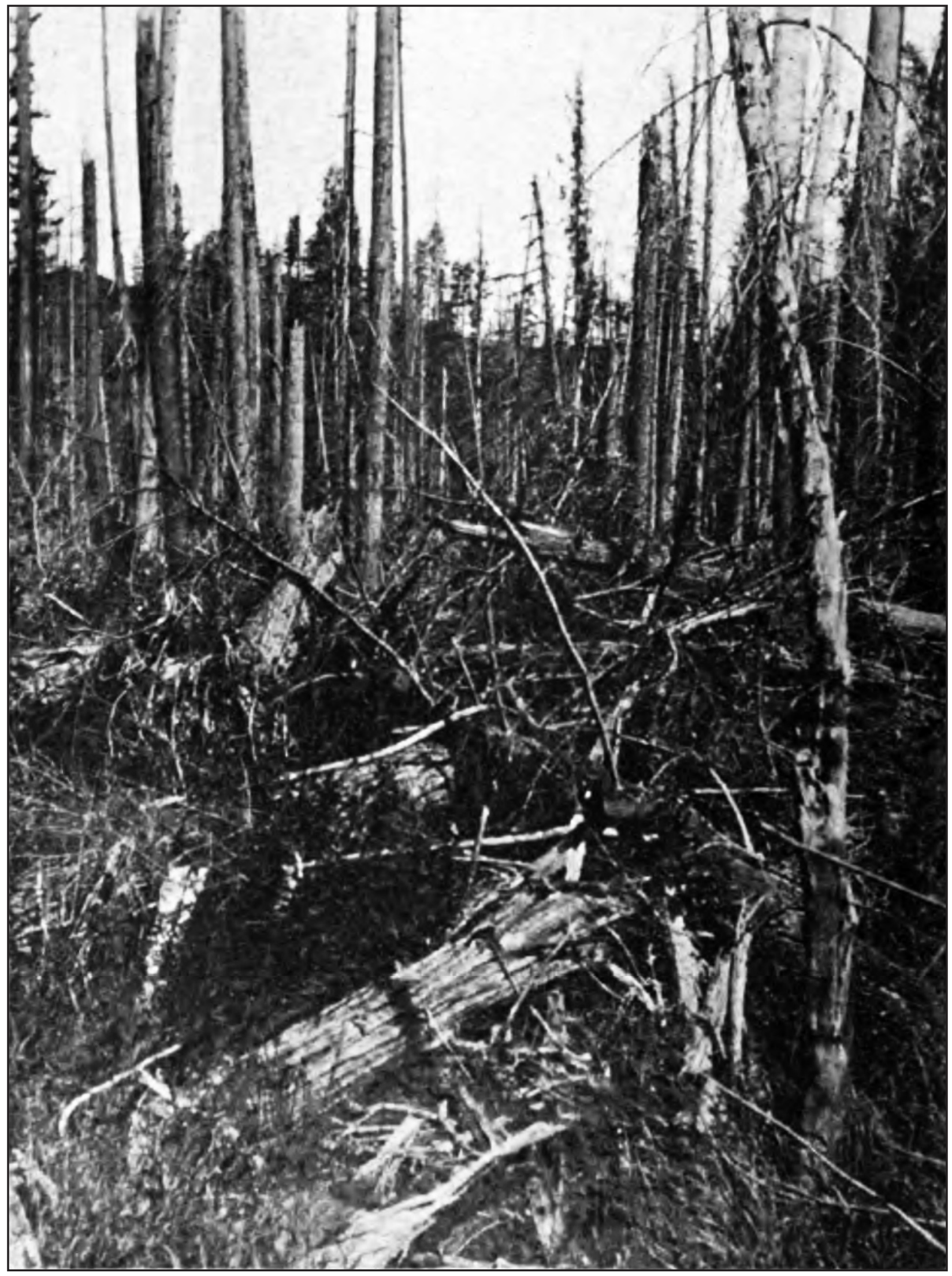

Figure 1. Fallen and standing fire-killed timber ready for the next fire- priest River Forest Reserve, Idaho. From "A Primer of Forestry." 


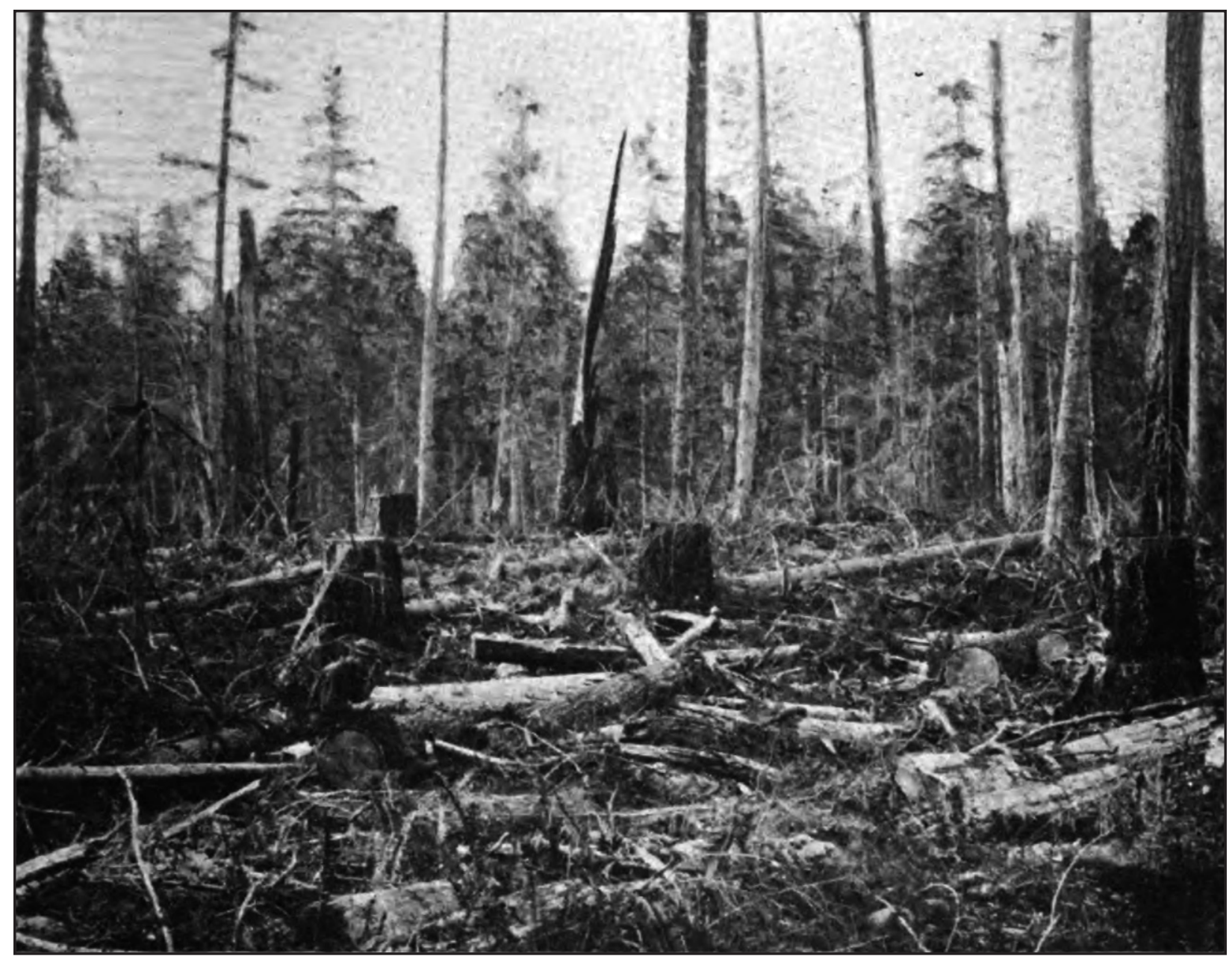

Figure 2. A slashing before the fire- the mass of debris is too thick to permit reproduction-western Washington.

tion, and in addition the behavior of the border forest lands along the eastern edge of the prairies powerfully confirms this view. Where such forest lands have been protected from fire, as they have very largely through the progress of settlement, young trees have usually sprung up in great numbers under or between the scattered veterans which had survived the fires, and dense and vigorous young growth stands ready to replace by a heavy forest the open park-like condition which the fire had created and maintained. The well known "oak openings" furnish an excellent case in point. In a similar way and for similar reasons trees are spreading from the borders of streams in the prairies to the grass lands near by. Such indications as these, joined to the occasional discovery of evidences of former tree growth out on the prairie, where trees no longer grow, go far to prove that trees once grew and may grow again much beyond the limits they occupied when the white man first entered the country. That fire was a restraining cause admits of no doubt whatever, and that it was the principal cause over vast areas is altogether probable. One set of facts which may ultimately be used to establish this latter contention is found in the positions chiefly or exclusively occupied by trees in semi-arid regions, which positions are either along water-courses, and so shielded from fire by moisture, or on rough and stony ground, and so protected by 


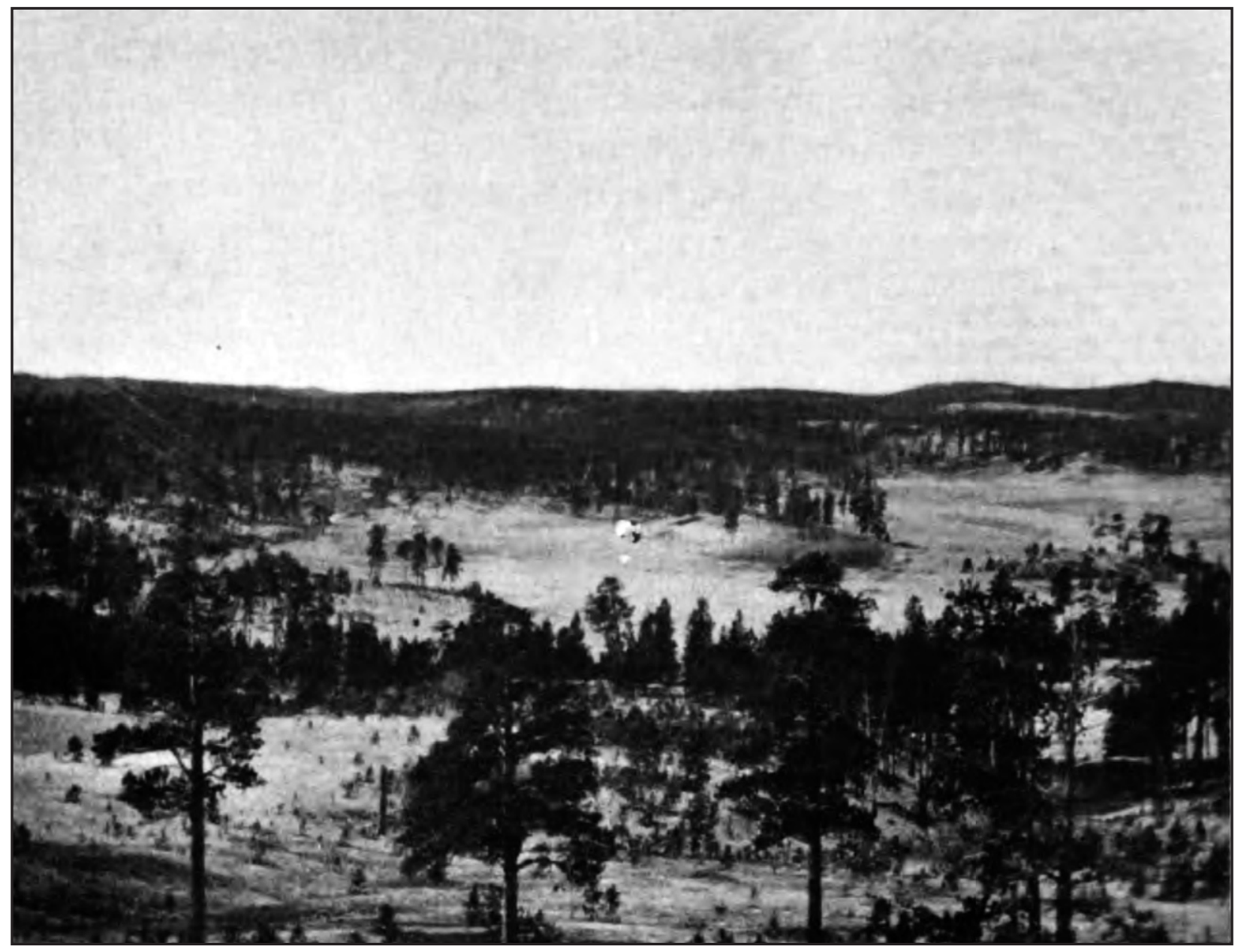

Figure 3. Fire glades surrounded by fire-scarred timber on higher ground-Black Hills, South Dakota.

the absence of enough grass or other vegetable groundcover to carry a destructive flame.

The same course of reasoning applies to certain kinds of open glades or prairie, well named "fire-glades" by Mr. Frederick V. Coville, Botanist of the U. S. Department of Agriculture. In the Black Hills of South Dakota, for example, these glades, surrounded by forest-bearing land, are almost exclusively confined to ground rich enough to support a crop of grass sufficiently dense to burn fiercely, while the timber is restricted to rough rocky or stony land, almost always higher than the glades and comparatively safe from fire because of the scantiness of minor vegetation it is able to support.
In semi-arid regions where fire-glades of this kind occur, there is an interesting alternation, by years or series of years, of the presence or absence of the moisture which makes forest reproduction possible. In the same way the occurrence or absence of burning gives or denies the opportunity for young seedlings to reach a size at which they are reasonably safe from the attacks of ordinary surface fires. It must be clearly borne in mind that it is only the average effect of the class of causes of which fire and rain are the chief of which we are concerned. Young trees sometimes succeed through combinations of temporary immunities in establishing themselves in the midst of fire-glades of old date, and the rocky 
refuges where some seedlings usually escape the fire are not uncommonly burned over, as the fire-scarred trunks abundantly testify. But these facts do not obscure the effective working of the averages, although they do tend powerfully to lengthen the time required for the average to work itself out. Thus reproduction around the fire-glades of the Black Hills is extremely slow.

Perhaps the most remarkable of the regulative effects of forest fires relates to the composition of the forest - the kinds of trees of which it is composed and the proportion of each. This effect depends on the action of fire in combination with the various qualities of resistance which trees possess. These qualities are of two chief kinds; one, adapted to secure the safety of the individual tree directly through its own powers of defense, the other to assure the continuance of the species, with little regard for the single tree. An example of the first kind is the western larch, whose enormously thick bark is almost fireproof, and so good a non conductor that it protects the living tissue beneath it even against fires hot enough to scorch the trunk 50 or 75 feet above the ground. It is to this quality of their bark, as well as to their marvelous vitality, that the big trees of California owe their power to reach an age of 3,000 or 4,000 years. The eastern pitch pine protects itself in the same way. So do many other trees, including longleaf pine, which adds to this quality of its bark another method of protection that places it at the head of all the trees of my acquaintance in its capacity to resist fire.

Almost all trees yield readily to slight surface fires during the first ten or fifteen years of their life. To this statement the longleaf pine is the conspicuous and rare exception. Not only do the young trees protect themselves in early youth by bark which is not uncommonly as thick as the wood (the whole diameter being thus two-thirds bark and one-third wood), but that add to this unusual armor a device special- ly adapted for their safety when growing amid long grass, usually a most fatal neighbor to young trees in the case of fire. It is to be noted that the vast majority of longleaf pines are associated with grass from the beginning to the end of their lives. During the first four or five years the longleaf seedling reaches a height of but four or five inches above the ground. It has generally been erroneously assumed that this slow growth made it specially susceptible to injury from fire; but while the stem during these early years makes little progress, the long needles shoot up and bend over in a green cascade which falls to the ground in a circle about the seedling. Not only does this barrier of green needles burn only with difficulty, but it shades out the grass around the young stem, and so prepares a double fire-resisting shield about the vitals of the young tree. Such facts explain why the fire which has restricted the spread of evergreen oaks in parts of Florida, for example, has made a pure forest of pines in a region where the reproduction of the oaks is phenomenally rapid wherever the annual fires cannot run.

The second method of protection against fire is that which sacrifices the individual but secures the safety of the species. Perhaps the most striking example of this method is furnished by the lodgepole pine, which is being distributed over hundreds of square miles in the Rocky Mountain region by the action of fire. It is a fact that this thin-barked tree, which succumbs with the utmost readiness to fire, is gaining ground by the action of its enemy, replacing over great areas thick-barked species like the red fir [Editor's note: now known as Douglas-fir] and the western larch (Figure 4). The device to which this curious result is due is similar to that of Pinus attenuata, to which John Muir long since called attention. It consists in the hoarding for several years of the ripe seeds in the cones. Fire rarely burns down the lodgepole pine, but in nearly every case

* See The Mountains of California, p. 151. 


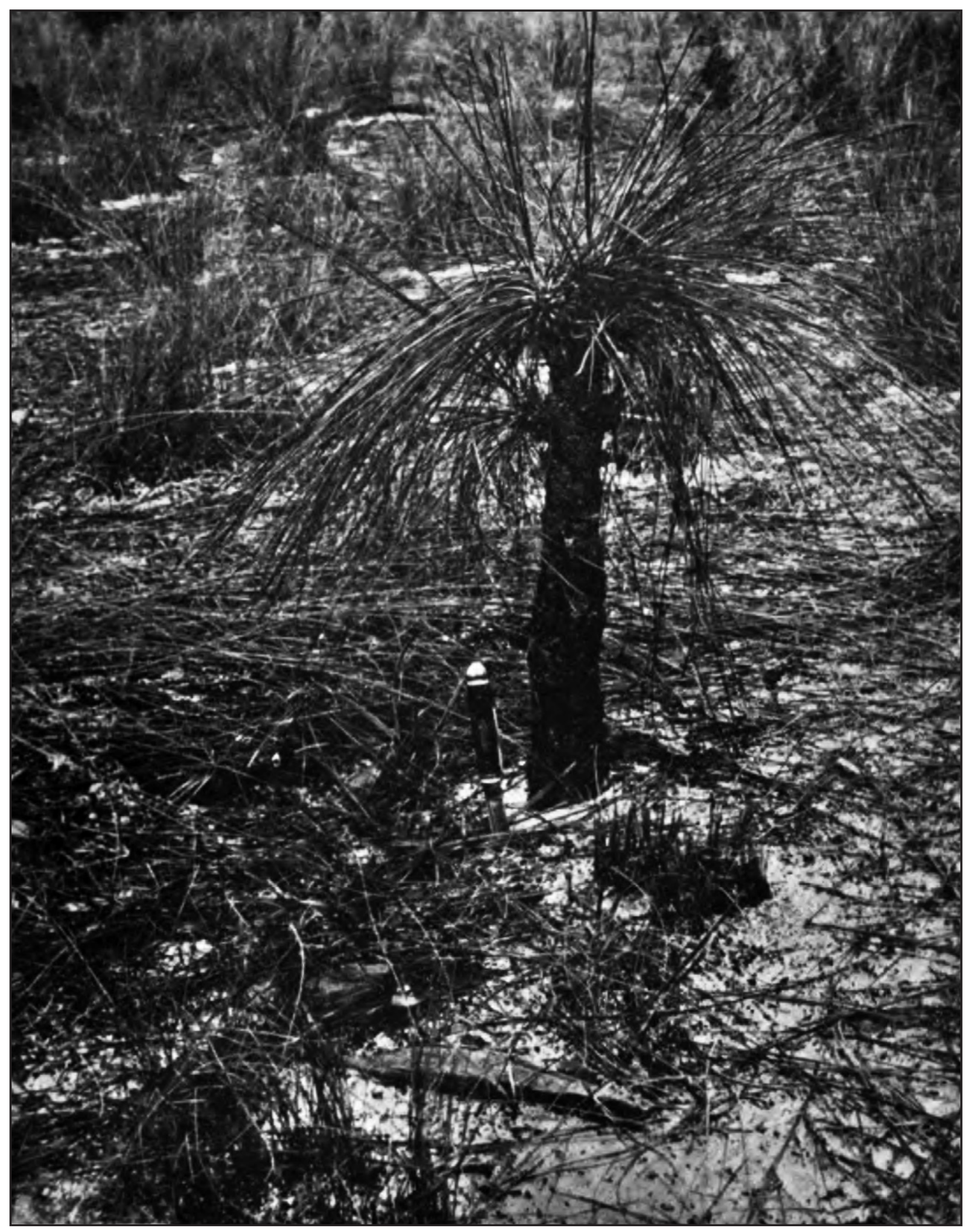

Figure 4. Fire-scarred seedling of longleaf pine - protecting natural growth of its needles. 
simply kills the standing tree and leaves it to be blown down years after when decay shall have weakened the roots (Figure 5). In the meantime the hoarded winged seeds are set free by the opening of the cones, are distributed and germinate, and the new crop contains a larger proportion of lodgepole than the old. By the repetition of this process great stretches of burned land are finally covered with a pure even-aged young growth where formally the forest was composed of other and usually more valuable species. The details of the return process by which the more valuable species will undoubtedly in the end regain possession of the soil I do not yet know.

A somewhat less obvious, although not less interesting, instance of distribution controlled by fire is that of the red fir in those proportions of Washington (and presumably of Oregon also) where it reaches its best dimensions and greatest commercial importance. Here the young seedlings are found in remarkable abundance on unshaded spots wherever the vegetable covering of the mineral soil has been burned away (Figure 6). An actual count and measurement of every tree on many hundred acres of fir timber in various parts of the Puget Sound region, and a study in the Olympics, combine to show them practically absent in the shade of their elders. In the latter region, as I had occasion to say in a report (dated January $26,1898)$ to the Secretary of the Interior on the condition and proper management of the national forest reserves, "Continuous stretches of

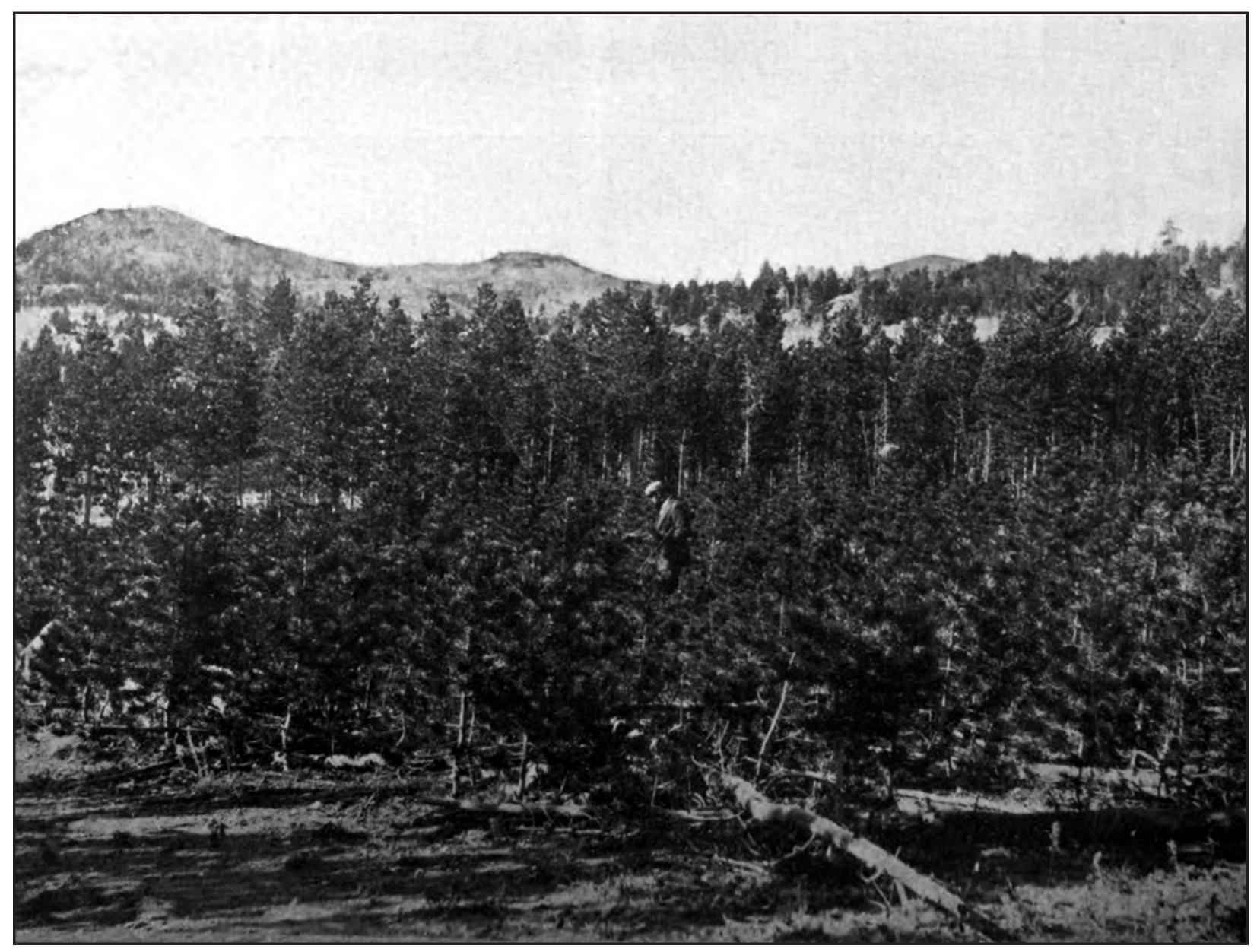

Figure 5. Two generations of lodgepole pine in even-aged growth after fire - the groups are twelve and fifty years old respectively. 


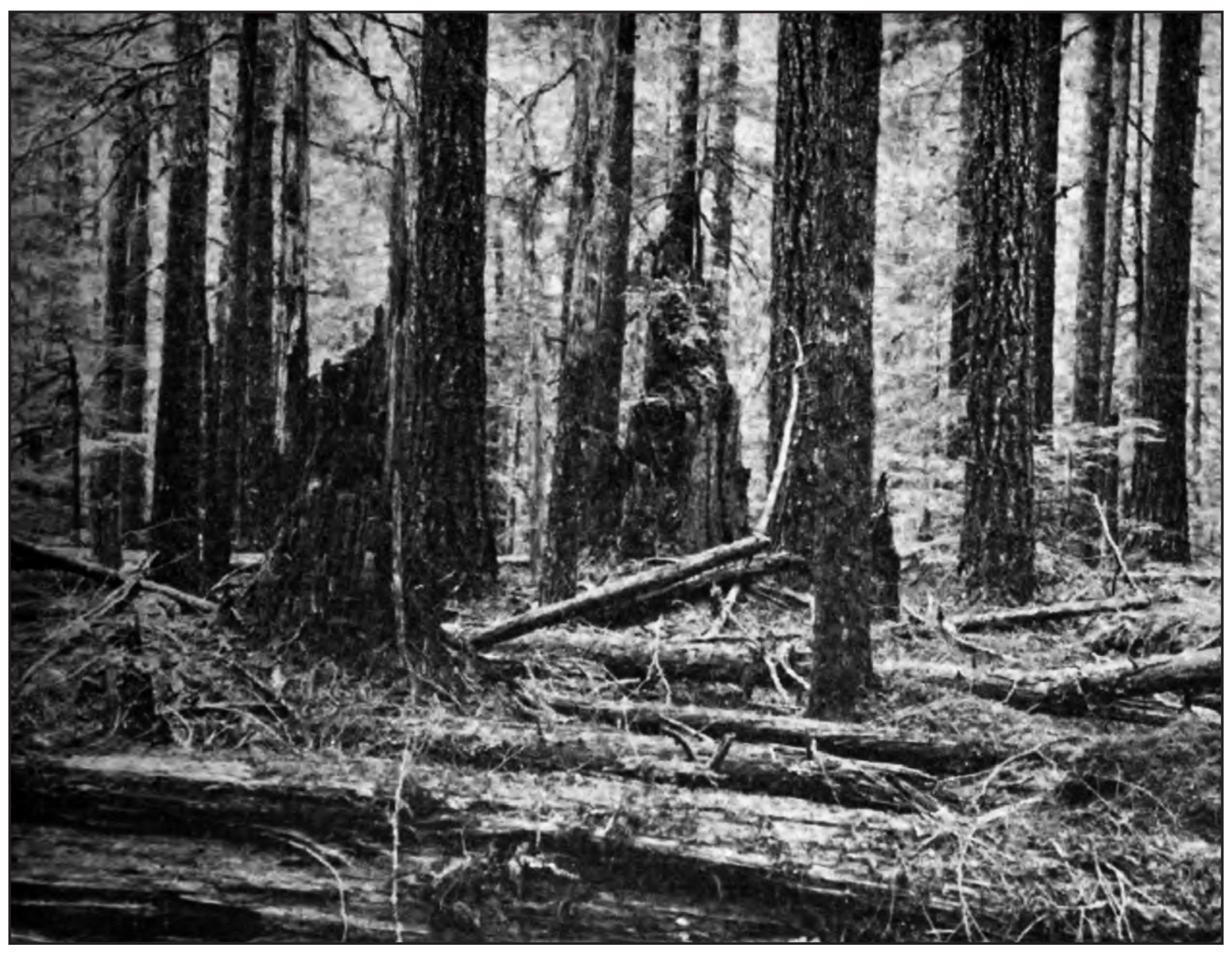

Figure 6. Unscarred even-aged young growth of red fir-showing fire scarred rotting stumps of the previous generation-Olympic Forest Reserve.

miles without a break were covered with a uniform growth of red fir from two to three feet in diameter, interspersed with numerous rotting stumps of much larger trees bearing the marks of fire (Figure 7). The young firs were entirely unscarred, but charcoal was found in the roots of the specimens which had been thrown by the wind. . . . Charcoal was found directly beneath a growing cedar tree four feet in diameter, under which a hole had been excavated in the course of lumbering operations. This mass of evidence acquires a crucial importance with relation to the forest from the act that in my ten days' visit to this region I did not see a single young seedling of Douglas fir (red fir) under the forest cover, nor a single opening made by fire which did not contain them." In a word, the distribution of the red fir in Washington, where it is by all odds the most valuable commercial tree, is governed, first of all, so far as we know at present, by fire. Had fires been kept out of these forests in the last thousand years the fir which gives them the distinctive character would not be in existence, but would be replaced in all probability by the hemlock, which fills even the densest of the Puget Sound forests with innumerable seedlings. I hasten to add that these facts do not imply any desirability in the fires which are now devastating the West.

These examples of the relations of fire and the forest are cited because they are conspicuous among the few which have already been worked out. Without question a number of re- 


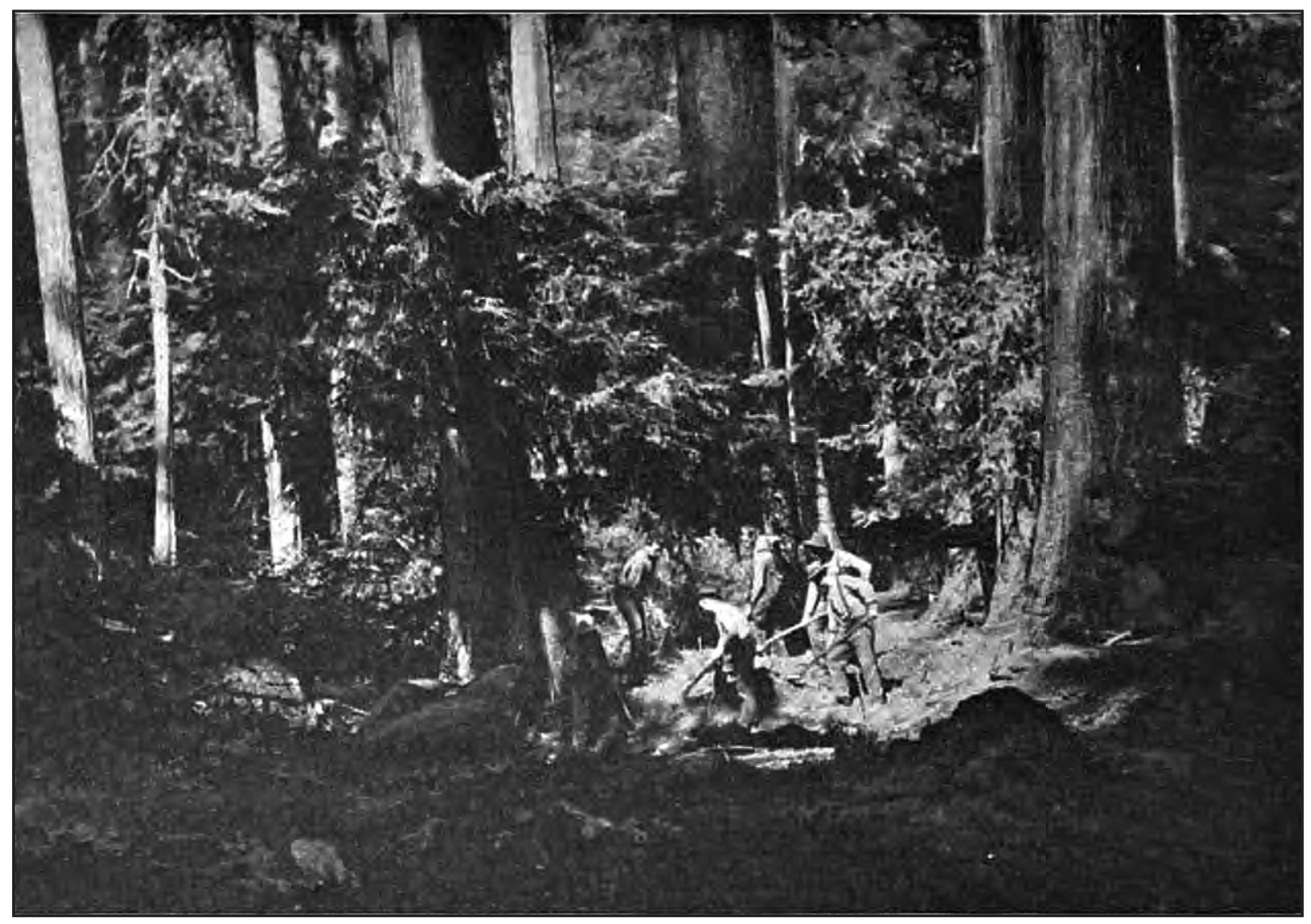

Figure 7. Red fir forest on land once ravaged by fire.

lations of vastly greater importance remain to attract and reward the student of this branch, one of the most fruitful and fascinating of all the fascinating and fruitful branches, of forestry in the United States.
Reprinted from National Geographic X(10): 393-403, October 1899. The journal appreciated the availability of the contents of this article through Google Book Search. 